\title{
Protect remaining roadless areas: The IENE 2014 declaration
}

\author{
IENE! \\ I IENE - Infra Eco Network Europe, clo Calluna AB, Linköping, Sweden \\ Corresponding authors: IENE( info@iene.info)
}

Academic editor: Klaus Henle | Received 9 July 2015 | Accepted 9 July 2015 | Published 28 July 2015

Citation: IENE (2015) Protect remaining roadless areas: The IENE 2014 declaration. In: Seiler A, Helldin J-O (Eds) Proceedings of IENE 2014 International Conference on Ecology and Transportation, Malmö, Sweden. Nature Conservation 11: 1-4. doi: 10.3897/natureconservation.11.5630

\section{Introduction}

Today's transport systems with their supporting infrastructure entail substantial environmental impacts and consume non-renewable natural resources including our most limited asset: space. With ever more roads and railways being built or upgraded, further encroachment on and disturbance of natural living spaces is inevitable (Laurance et al. 2014). Much of this development takes place in developing countries, but also in Europe, and especially in eastern countries, new transport infrastructures lead to significant loss and fragmentation of habitat (Jaeger et al. 2011). Although the consequent threats to biodiversity are well understood, existing tools and strategies to prevent further fragmentation and continued loss of biodiversity appear not sufficiently effective (European Commission 2010). Even in the Impact Assessment of the European White Paper on Transportation (European Commission 2011), habitat fragmentation is merely recognized but not solved. In response, European countries engage in developing a green infrastructure of networks of habitats that shall re-linking nature protection sites across fragmented landscapes (European Commission 2013). Transportation corridors are major obstacles to this endeavour, but they can be overcome and even partly integrated in the design of green infrastructure (IENE 2012). 
In fact, many of the direct and immediate threats of roads and railroads can be partly overcome or at least minimised (Iuell et al. 2003; van der Ree et al. 2015). It is also evident, however, that not all negative impacts can be mitigated or compensated for. There will always be a residual detrimental effect on nature. It is therefore only logical to conclude that in certain areas, where these residual effects are not acceptable, construction of transport facilities should be entirely avoided. Such areas need to remain (or become again) roadless to provide sufficient undisturbed space for nature conservation (DeVelice and Martin 2001, Crist et al. 2005). Even within Europe, where only small and few roadless areas reside (Selva et al. 2011, 2015), this need is increasingly recognised.

To support this development and highlight the value of roadless areas as complements to current biodiversity conservation in Europe, the participants at the IENE 2014 international conference (Seiler 2014) unequivocally asked for a pan-European strategy on roadless areas.

The following text is copied from the IENE 2014 website (http://iene2014.iene. info/iene-2014-declaration/):

\section{The IENE 2014 declaration: Protect remaining roadless areas}

"We, the participants of the IENE 2014 International Conference on Ecology and Transportation, acknowledge that:

- the mobility of people and goods is important for economic development; transportation facilities such as roads, railroads and canals bring benefit to people and are essential components of present-day human societies,

- transportation infrastructure with its associated traffic exerts substantial pressures on biodiversity that extend far from individual transportation corridors and may interact and even accumulate at network level,

- even minor infrastructure is of significance as it prepares for exploitation of natural resources and secondary development,

- the detrimental environmental impacts of traffic and transportation infrastructure can only in part be mitigated effectively, but not entirely avoided.

Roadless areas are of particular importance for biodiversity conservation, because they

- $\quad$ are the least disturbed natural areas in the world,

- are characterized by high ecological value, integrity and connectivity,

- act as refuges for native and endangered wild animals and plants,

- provide vital ecosystem services such as clean water and air, opportunities for recreation, and protection against pests and invasive species,

- are more resistant to and resilient from catastrophic events,

- help species to adapt to new conditions created by climate and landscape change. 
Thus, roadless areas far exceed roaded areas in the ecological benefits they provide. Europe has been fragmented by transportation infrastructure for a long time. Accordingly, preserving the continent's last remaining roadless areas will significantly contribute to prevent further loss of biodiversity. Preserving roadless areas is hence necessary for reaching the UN Aichi strategic goals and EU biodiversity targets.

Therefore we, the participants of the IENE 2014 International Conference, call for a pan-European strategy to protect roadless areas.

We urge that such areas are given a stronger conservation status in policy, planning and practice, both nationally and internationally, by

- mapping and monitoring roadless areas at national as well as European level,

- incorporating roadless areas explicitly as conservation targets in national and European policy and legislation,

- avoiding infrastructure development in roadless areas,

- identifying areas of particular value for restoration as roadless areas,

- regularly monitor and evaluate the efforts to protect roadless areas,

- re-creating roadless areas by means of road closure and removal.

The IENE 2014 International Conference has highlighted the ecological and social benefits of roadless areas, outlined solutions for how transportation infrastructure can be developed without compromising these benefits, and shown that the transport sector is able and willing to contribute substantially to implementing these solutions."

\section{References}

Crist MR, Wilmer BO, Aplet GH (2005) Assessing the value of roadless areas in a conservation reserve strategy: Biodiversity and landscape connectivity in the northern Rockies. Journal of Applied Ecology 42: 181-191. doi: 10.1111/j.1365-2664.2005.00996.x

DeVelice RL, Martin JR (2001) Assessing the extent to which roadless areas complement the conservation of biological diversity. Ecological Applications 11(4): 1008-1018. doi: 10.1890/1051-0761(2001)011[1008:ATETWR]2.0.CO;2

European Commission (2010) Options for an EU vision and target for biodiversity beyond 2010. European Commission, $\operatorname{COM(2011)~} 144$ final, Brussels. http://ec.europa.eu/environment/nature/biodiversity/policy/pdf/

European Commission (2011) Roadmap to a Single European Transport Area - Towards a competitive and resource efficient transport system: Impact Assessment. European Commission, SEC(2011) 358 final, Brussels. http://eur-lex.europa.eu/LexUriServ/LexUriServ. do?uri=SEC:2011:0358:FIN:EN:PDF

European Commission (2013) Green Infrastructure (GI) - enhancing Europe's natural capital. European Commission, $\operatorname{COM}(2013) 249$ final, Brussels. http://eur-lex.europa.eu/resource.html?uri=cellar:d41348f2-01d5-4abe-b817-4c73e6f1b2df.0014.03/ DOC_1\&format=PDF 
IENE (2012) Potsdam Declaration: Overcome Barriers - Europe-wide and now. http:// iene2012.iene.info/wp-content/uploads/2013/07/IENE-2012-Potsdam-declaration.pdf [accessed July 01.2015]

Iuell B, Bekker H, Cuperus R, Dufek J, Fry GL, Hicks C, Hlavac V, Keller J, Le Marie Wandall B, Rosell Pagès C, Sangwine T, Torslov N (Eds) (2003) Wildlife and Traffic - A European Handbook for Identifying Conflicts and Designing Solutions. Prepared by COST 341 Habitat Fragmentation due to Transportation Infrastructure. Ministry of Transport, Public Works and Water Management, Road and Hydraulic Engineering division, Delft, The Netherlands. http://www.iene.info/wp-content/uploads/COST341_Handbook.pdf

Jaeger JLFM, Soukup T, Schwick C, Kienast F (2011) Landscape fragmentation in Europe. A joint EEA-FOEN report. European Environment Agency, Copenhagen, 87 pp. http:// www.eea.europa.eu/publications/landscape-fragmentation-in-europe

Laurance WF, Clements GR, Sloan S, O’Connell CS, Mueller ND, Goosem M, Venter O, Edwards DP, Phalan B, Balmford A, Van Der Ree R, Arrea IB (2014) A global strategy for road building. Nature advance online publication. doi: 10.1038/nature13717

Seiler A (Ed.) (2014) IENE 2014 International Conference on Ecology and Transportation, Programme and Abstracts. Calluna AB, Malmö. http://iene2014.iene.info/wp-content/ uploads/IENE_2014_Proceedings_updated_version.pdf

Selva N, Kreft S, Kati V, Schluck M, Jonsson BG, Mihok B, Okarma H, Ibisch PL (2011) Roadless and low-traffic areas as conservation targets in Europe. Environmental Management 48: 865-877. doi: 10.1007/s00267-011-9751-z

Selva N, Switalski A, Kreft S, Ibisch PL (2015) Why Keep Areas Road-Free? The Importance of Roadless Areas. Handbook of Road Ecology. John Wiley \& Sons, Ltd., 16-26. doi: 10.1002/9781118568170.ch3

van der Ree R, Smith DJ, Grilo C (2015) The Ecological Effects of Linear Infrastructure and Traffic. Handbook of Road Ecology. John Wiley \& Sons, 1-9. doi: 10.1002/9781118568170.ch1 